\title{
Toxicity of organic farming-compatible products to the coffee leaf miner
}

\author{
Madelaine Venzon(1), Rodrigo Ferreira Krüger(2), Alberto Soto(3), Edmar de Souza Tuelher ${ }^{(1)}$, \\ Italo Santos Bonomo(1), Marcos Antonio Matiello Fadini(4) and Maira Christina Marques Fonseca(1)
}

\begin{abstract}
(1)Empresa de Pesquisa Agropecuária de Minas Gerais, Vila Gianetti, no 46, CEP 36570-000 Viçosa, MG, Brazil. E-mail: venzon@epamig.br, estuelher@yahoo.com.br, maira@epamig.br, italo_bonomo@yahoo.com.br (2)Universidade Federal de Pelotas, Campus Universitário Capão do Leão, s/no, CEP 96010-900 Pelotas, RS, Brazil. E-mail: rodrigo.kruger@ufpel.edu.br (3)Universidad de Caldas, Calle 65, ํo 26-10, Manizales, Caldas, Colombia. E-mail: asotog@hotmail.com ${ }^{(4)}$ Universidade Federal de São João Del Rei, Campus Sete Lagoas, Rodovia MG-42, Km 47, CEP 35701-970 Sete Lagoas, MG, Brazil. E-mail: fadini@ufsj.edu.br
\end{abstract}

\begin{abstract}
The objective of this work was to evaluate the toxicity of organic farming-compatible products to the coffee leaf miner Leucoptera coffeella. Lime sulphur, enriched Bordeaux mixture (Viça Café Plus), and the "supermagro" biofertilizer were first tested in laboratory. The most promising product was tested afterwards under field conditions. In laboratory, different concentrations of each product were applied on $L$. coffeella eggs and on infested coffee-mined leaves. Only lime sulphur had ovicidal effects at an acceptable concentration (1.6\%) for field applications, but no significant effect on larvae mortality was found. Enriched Bordeaux mixture and the "supermagro" biofertilizer had no effect on L. coffeella eggs and larvae. In the field trial, biweekly or monthly sprayings of lime sulphur at different concentrations caused population decrease after 30 days; however, this effect was not significant after 60 or 90 days.
\end{abstract}

Index terms: Leucoptera coffeella, biofertilizer, Bordeaux mixture, lime sulphur.

\section{Toxicidade de produtos compatíveis com a agricultura orgânica ao bicho-mineiro do cafeeiro}

\begin{abstract}
Resumo - O objetivo deste trabalho foi avaliar a toxicidade de produtos compatíveis com a agricultura orgânica ao bicho-mineiro Leucoptera coffeella. A calda sulfocálcica, a calda Viçosa comercial (Viça Café Plus) e biofertilizante supermagro foram testados inicialmente em laboratório. O produto mais eficaz foi posteriormente testado em condições de campo. Em laboratório, diferentes concentrações de cada produto foram aplicadas sobre ovos de L. coffeella e sobre folhas de café infestadas com o bicho-mineiro. Apenas a calda sulfocálcica teve efeito ovicida a uma concentração (1,6\%), viável para aplicação no campo; porém, sem nenhum efeito significativo sobre a mortalidade das larvas. A calda Viçosa comercial e o biofertilizante supermagro não tiveram efeito sobre ovos e larvas de $L$. coffeella. No experimento de campo, a pulverização quinzenal ou mensal de diferentes concentrações da calda causou a redução da população 30 dias após a aplicação; no entanto, esse efeito não foi significativo após 60 ou 90 dias.
\end{abstract}

Termos para indexação: Leucoptera coffeella, biofertilizante, calda Viçosa, calda sulfocálcica.

\section{Introduction}

Pest management in organic systems relies on ecological strategies to prevent pests from reaching damaging levels (Zehnder et al., 2007). Curative measures are applied only when the preventive tactics fail to restrain pest population growth. These measures include the use of nonsynthetic products approved by national organic standard organizations. In Brazil, organic coffee growers often spray a large array of organic farming-compatible products aiming at controlling the coffee leaf miner Leucoptera coffeella
Guérin-Mèneville (Lepidoptera: Lyonetiidae), one of the key coffee pests (Reis et al., 2002; Pereira et al., 2007). Among organic farming-compatible products used for organic coffee production are botanical extracts, biofertilizers, sulphur based products and Bordeaux mixture. They can be easily prepared by farmers at low cost. Except for some botanical extracts, mainly neem-based products (Martinez \& Meneguim, 2003; Venzon et al., 2005), most of these products have not yet been proven to be effective for coffee leaf miner control. 
A Bordeaux mixture, enriched with micronutrients, known in Brazil as "calda Viçosa" (Viça Café Plus), has been traditionally used by small holders for coffee nutrition and for disease and pest control (Herrera, 1994; Androcioli et al., 2012). However, in a long-term field experiment, Herrera (1994) found no significant correlation between coffee leaf miner population and applications of a homemade "calda Viçosa". Although farmers have used this enriched Bordeaux mixture in an attempt to control L. coffeella, there is no evidence of its efficacy in controlling the pest.

Another product that has been used more often in organic coffee production is lime sulphur, a mixture of calcium polysulfides, obtained by boiling calcium hydroxide and sulphur. It is a well-known fungicide (Smilanick \& Sorenson, 2001; Holb et al., 2003) and pesticide against mites and scales (Afonso et al., 2007; Beers et al., 2009; Kim et al., 2010; Venzon et al., 2013). However, its efficacy against lepidopteran pests has not been documented yet.

Biofertilizers are largely applied in organic plantations to improve plant nutrition, but are also applied to control pests and diseases (Silva \& Carvalho, 2000; Medeiros et al., 2003). One of the most popular biofertilizers used by organic coffee farmers in Brazil is the "supermagro". It contains fresh bovine manure diluted in water and is supplemented with a mixture of proteins, micronutrients, unrefined sugar, and milk to stimulate fermentation (Silva \& Carvalho, 2000).

Regardless of their common use by organic farmers, there is no scientific evidence of their efficacy in controlling coffee leaf miner.

The objective of this work was to evaluate the toxicity of organic farming-compatible products to the coffee leaf miner L. coffeella.

\section{Materials and Methods}

Coffee leaf miners were obtained by collecting infested leaves from an experimental coffee plantation, at the campus of the Universidade Federal de Viçosa, in the state of Minas Gerais, Brazil. Leaves were taken to the laboratory at the Empresa de Pesquisa Agropecuária de Minas Gerais (Epamig). Their petioles were inserted into a sponge soaked in water solution of benzyladenine $\left(10 \mu \mathrm{mol} \mathrm{L} \mathrm{L}^{-1}\right)$ - a plant growth regulator - in order to increase the lifetime of the leaves (Reis Junior et al., 2000), which were then placed inside acrylic boxes $(11.0 \times 11.0 \times 3.5 \mathrm{~cm})$. After pupation, sections of leaves containing $L$. coffeella pupae were transferred to plastic tubes $(8.0 \times 3.0 \mathrm{~cm})$ covered with a plastic lid and kept until adult emergence. Adults were used either for experiments or for stock rearing, and were kept inside climate chambers at $25 \pm 2^{\circ} \mathrm{C}$, with $70 \pm 10 \%$ relative humidity and 14-hour photophase.

The organic farming-compatible products tested in the laboratory were: a commercial formulation of enriched Bordeaux mixture Viça Café Plus (10.0\% $\mathrm{K}, 8.2 \% \mathrm{Zn}, 3.0 \% \mathrm{~B}, 1.0 \% \mathrm{Mg}, 10.0 \% \mathrm{Cu}, 13.5 \% \mathrm{~S}$, and $5 \mathrm{~g} \mathrm{~L}^{-1}$ hydrated lime; a fresh made lime sulphur (250 $\mathrm{g} \mathrm{L}^{-1} \mathrm{~S}$ and $125 \mathrm{~g} \mathrm{~L}^{-1}$ calcium hydroxide); and a "supermagro" biofertilizer. Supermagro contains fresh bovine manure diluted in water and is supplemented with micronutrients $(\mathrm{Zn}, \mathrm{Mg}, \mathrm{Mn}, \mathrm{Cu}, \mathrm{Co}, \mathrm{Ca}, \mathrm{B}, \mathrm{Fe}$ and $\mathrm{Na}$ ), bone meal, unrefined sugar, and milk, to stimulate fermentation.

Effects of these three products on L. coffeella eggs and larvae were evaluated in separated experiments. In the first series of experiments, products were applied on leaves containing $L$. coffeella eggs, and in the second series, the same products were applied on leaves containing mines with $L$. coffeella larvae inside. In order to obtain leaves with sufficient eggs, coffee leaves were collected from potted plants (10 to 12-month-old Coffea arabica L., Cultivar Catuaí, kept in a greenhouse at Epamig). Coffee leaves were placed inside acrylic boxes with their petioles inserted into a soaked sponge, as previously described. The boxes with leaves were placed inside wooden framed cages $(50 \times 50 \times 50 \mathrm{~cm})$ covered with gauze. Approximately 60 two-day-old adults of $L$. coffeella were released into the cages for two days, to allow adults mating and female oviposition. It was assumed a 1:1 sex ratio. Two-day-old adults were used to ensure the highest levels of female fecundity and egg viability (Michereff et al., 2004). Three cages containing 60 adults of L. coffeella were used simultaneously, in order to obtain sufficient eggs for each experiment. Leaves were removed, and the number of eggs on each leaf was counted. The number of eggs per leaf was standardized by removing surplus eggs and leaving 10 eggs per leaf.

Tested product concentrations in the experiments included the average field rates applied for pest and disease control on coffee (Silva \& Carvalho, 2000; Tuelher, 2006), besides lower and higher concentrations in order to obtain a range of response. The concentrations tested for Viça Café Plus were 0.1, 
$0.5,1.0,2.5$ (the average field rate concentration), $5.0,7.5$, and $10.0 \%(\mathrm{v} / \mathrm{v})$; for "supermagro" biofertilizer, concentrations were 1.0, 25.0 (the average field rate concentration), 50.0, 75.0, and $100 \%(\mathrm{v} / \mathrm{v})$; and, for lime sulphur ( $32^{\circ}$ Baumé), concentrations were $0.005,0.05,0.5,2.5$ (the average field rate), 5.0, and $10 \%(\mathrm{v} / \mathrm{v})$. An equal volume of the products $(2.5 \mathrm{~mL})$ was sprayed on leaves with eggs, using a Potter tower (Burkard, Rickmansworth, UK) under 0.34 bar pressure $\left(=3.44 \times 10^{4} \mathrm{kPa}\right)$. After leaves had dried, they were positioned vertically by inserting their petioles into a soaked sponge in the benzyladenine solution and, then, they were placed inside acrylic boxes. Leaves were kept inside climate chambers at $25 \pm 2^{\circ} \mathrm{C}, 70 \pm 10 \% \mathrm{RH}$ and 14-hour photophase. After six days, egg eclosion was evaluated.

The experiments were carried out using a completely randomized design. Each replicate consisted of a leaf with $10 \mathrm{~L}$. coffeella eggs. For each product, the number of replicates per treatment varied according to the number of leaves obtained with 10 eggs of L. coffeella of the same age. For Viça Café Plus, the number of replicates per concentration varied from five to eight ( $\mathrm{n}=52)$; for the "supermagro" biofertilizer, six replicates were used for each concentration $(n=36)$; and, for lime sulphur, four replicates were used for each tested concentration $(\mathrm{n}=28)$.

Product toxicity to $L$. coffeella larvae was evaluated by spraying the products on coffee mines according to Venzon et al. (2005). To obtain coffee leaves with mines, the same procedure described for the eggs was followed, but, this time, leaving four eggs per leaf positioned at least $1.5 \mathrm{~cm}$ apart. Since the objective was to measure the effect of the products on larval development, the number of eggs was standardized. Due to endophytic larval feeding behavior, it was difficult to measure larval development. Thus, as mine size increased with larval developmental stages, the final mine size was used as an indirect measure. Leaving more than four eggs per leaf would have impeded measuring individual mine size, since mines coalesce as they increase in size. Leaves were treated only after mine formation had begun $(1.2 \mathrm{~mm}$ average length). Only leaves with four mines were used in the experiments. The following concentrations were tested, based on field rates, as explained above: Viça Café Plus, 1, 2, 4, 6 e 10\% (v/v); "supermagro" biofertilizer, $10,20,40,60,80$, and 100\% (v/v); and lime sulphur, 2,
$4,6,8$, and $10 \%(\mathrm{v} / \mathrm{v})$. The control treatment consisted of leaves sprayed with water. Treated leaves were kept under the same conditions described for the egg experiments. The influence of product concentration was evaluated based on the following variable responses: mine area size after $L$. coffeella pupation, which was measured using a leaf area measurement system (Delta-T Devices Ltd., Cambridge, UK); number of pupae formed per leaf; and number of emerged adults per leaf. The experiments were carried out using a completely randomized design. Treatments (concentrations) were repeated five times for Viça Café Plus ( $n=30)$, "supermagro" biofertilizer $(n=35)$, and lime sulphur $(\mathrm{n}=30)$. Each replicate consisted of a leaf with four L. coffeella mines.

A field experiment was carried out to evaluate the effect of lime sulphur concentrations - the only product which showed negative effects upon L. coffeella -, applied at different time intervals, on a coffee leaf miner population. The experiment was carried out at the Experimental Station of Epamig, in the municipality of Oratórios $\left(20^{\circ} 24^{\prime} \mathrm{S}, 42^{\circ} 48^{\prime} \mathrm{W}\right)$, MG, Brazil, from May to August 2007, during part of the region's dry season and under favorable climate conditions for L. coffeella (Pereira et al., 2007). Five lime sulphur concentrations $(0.5,1.0,1.5,2.0$, and $2.5 \%, \mathrm{v} / \mathrm{v})$ were applied either biweekly or monthly. Concentrations were chosen based on field rates used by organic coffee farmers, and on the results obtained from the laboratory experiments. Higher concentrations were not tested, due to the possibility of causing phytotoxicity symptoms, as reported for other crops (Holb et al., 2003; Palmer et al., 2003).

A split-plot design was used with five blocks. Each block was divided into six plots which received one lime sulphur concentration or water application (control treatment). Each plot was divided into two subplots which received the treatment application either biweekly or monthly over the course of 90 days. Plants were sprayed with the tested concentration using a knapsack sprayer Brudden SS model with 20 L capacity and a hollow cone nozzle of $400 \mathrm{~L} \mathrm{ha}^{-1}$ average volume. Each plot consisted of 28 coffee plants (C. arabica, cultivar "Catuaí") under commercial production age (about 10 years old) with $3 \mathrm{~m}$ spacing between lines and $1.2 \mathrm{~m}$ between plants. Data were collected from the six central plants, which were sampled monthly by collecting 60 leaves from 
three of the six central plants. Specifically, 20 leaves were collected per plant from the third and fourth pairs of leaves from branches located on the superior third of the canopy, the preferred oviposition site of $L$. coffeella. Leaves were taken to the laboratory and screened for $L$. coffeella mines. Only intact mines were counted. Mines with signs of adult emergence or wasp predation were excluded from the analysis.

Treatment mortalities in laboratory were corrected using Abbott's formula (Abbott, 1925), and the influence of product concentration of each explanatory variable on the probability of egg mortality, number of formed pupae, and emerged adults were analyzed by Probit procedure. Probit regression models were constructed with logarithm of base 10 of concentration. Mine area after L. coffeella pupation was analyzed by linear regression with $\mathrm{F}$ distribution.

Field data experiment fit a Poisson distribution with a correction function (quasi-Poisson) for data overdispersion due to high variability, which is in accordance with Crawley (2007). To avoid pseudoreplication, data analyses were performed for each 30-day period after the first spraying $(30,60$, and 90 days), and Chi-square tests were run for comparison between the model built with the explanatory variables - lime sulphur concentration, treatment application frequency (biweekly or monthly), and interactions of those variables - and the null model with generalized linear model. The analyzed data represent the total number of mines on 60 leaves per treatment per sampling $(30,60$, and 90 days from the beginning of the experiment), under different concentrations of lime sulphur. Statistical analyses were performed using $\mathrm{R}$ software (R Development Core Team, 2011) at 5\% probability.

\section{Results and Discussion}

There was no significant difference among tested concentrations of Viça Café Plus on L. coffeella egg mortality (Figure 1). Also, spraying coffee leaf mines with Viça Café Plus did not cause a significant difference on the final mine size, on the number of formed pupae per leaf or on the number of emerged adults per leaf (Table 1). Tested concentrations of Viça Café Plus did not cause significant egg and larvae mortality, even at concentrations higher than those commonly used by farmers, which is approximately $2 \%$. Similar results were reported by Michereff-Filho et al. (2008) for

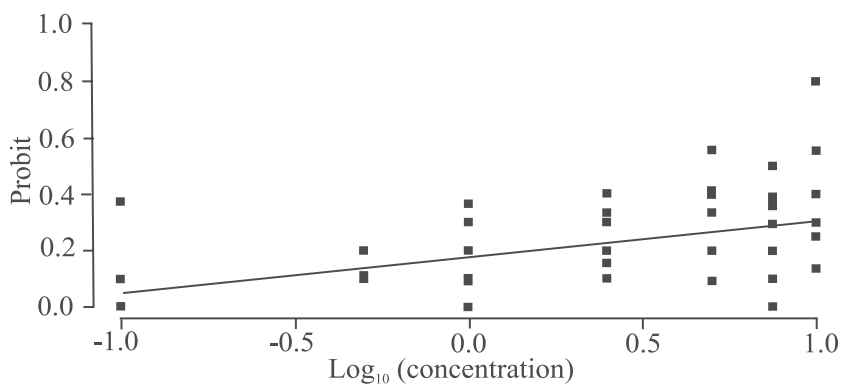

Figure 1. Probit regression line of Viça Café Plus concentrations on Leucoptera coffeella eggs treated on coffee leaves $\left(\mathrm{Chi}=1.6, \mathrm{df}=51, \mathrm{p}=0.210, \mathrm{R}^{2}=0.19\right)$.

Table 1. Laboratory development of Leucoptera coffeella in mines of coffee leaves treated with Viça Café Plus, "supermagro", and lime sulphur.

\begin{tabular}{|c|c|c|c|}
\hline Concentration (\%) & Mine area $\left(\mathrm{cm}^{2}\right)$ & Pupae per leaf & Emerged adults per leaf \\
\hline & \multicolumn{3}{|c|}{ Viça Café Plus } \\
\hline 0 & $1.33 \pm 0.24$ & $2.00 \pm 1.58$ & $2.00 \pm 1.58$ \\
\hline 1 & $1.28 \pm 0.13$ & $3.20 \pm 1.10$ & $2.80 \pm 0.84$ \\
\hline 2 & $0.89 \pm 0.16$ & $2.80 \pm 1.10$ & $2.80 \pm 1.10$ \\
\hline 4 & $1.36 \pm 0.14$ & $3.20 \pm 0.84$ & $3.00 \pm 1.00$ \\
\hline 6 & $1.10 \pm 0.08$ & $3.40 \pm 0.89$ & $3.40 \pm 0.89$ \\
\hline 10 & $1.12 \pm 0.24$ & $3.20 \pm 1.10$ & $3.20 \pm 1.10$ \\
\hline Average & $1.18 \pm 0.33$ & $2.97 \pm 1.13$ & $2.87 \pm 1.11$ \\
\hline F value & 0.45 & - & - \\
\hline Chi square-value & - & 0.00 & 0.26 \\
\hline df & 29 & 29 & 29 \\
\hline \multirow[t]{2}{*}{$\mathrm{p}$ value } & 0.507 & 1.000 & 0.610 \\
\hline & \multicolumn{3}{|c|}{ Supermagro } \\
\hline 0 & $1.38 \pm 0.07$ & $2.00 \pm 1.22$ & $2.00 \pm 1.22$ \\
\hline 10 & $0.88 \pm 0.08$ & $2.60 \pm 1.14$ & $2.40 \pm 0.89$ \\
\hline 20 & $0.90 \pm 0.08$ & $1.80 \pm 1.30$ & $1.80 \pm 1.30$ \\
\hline 40 & $0.96 \pm 0.09$ & $2.80 \pm 0.44$ & $2.20 \pm 0.44$ \\
\hline 60 & $0.93 \pm 0.18$ & $2.20 \pm 1.48$ & $2.00 \pm 1.58$ \\
\hline 80 & $1.16 \pm 0.23$ & $2.60 \pm 1.34$ & $2.40 \pm 1.14$ \\
\hline 100 & $0.61 \pm 0.15$ & $1.60 \pm 0.89$ & $1.60 \pm 0.89$ \\
\hline Average & $0.97 \pm 0.34$ & $2.23 \pm 1.15$ & $2.06 \pm 1.07$ \\
\hline F-value & 4.9 & - & - \\
\hline Chi square-value & - & 0.07 & 0.14 \\
\hline df & 34 & 34 & 34 \\
\hline \multirow[t]{2}{*}{ p-value } & 0.051 & 0.790 & 0.700 \\
\hline & \multicolumn{3}{|c|}{ Lime sulphur } \\
\hline 0 & $1.24 \pm 0.23$ & $0.60 \pm 0.89$ & $0.40 \pm 0.55$ \\
\hline 2 & $1.25 \pm 0.24$ & $2.60 \pm 0.89$ & $2.40 \pm 0.89$ \\
\hline 4 & $1.14 \pm 0.08$ & $1.00 \pm 0.71$ & $0.80 \pm 0.84$ \\
\hline 6 & $1.12 \pm 0.17$ & $3.40 \pm 0,89$ & $2.80 \pm 1.30$ \\
\hline 8 & $1.10 \pm 0.13$ & $1.80 \pm 1.48$ & $1.20 \pm 1.30$ \\
\hline 10 & $1.02 \pm 0.09$ & $1.60 \pm 0.55$ & $1.40 \pm 0.55$ \\
\hline Average & $1.14 \pm 0.29$ & $1.83 \pm 1.29$ & $1.50 \pm 1.22$ \\
\hline F-value & 2.05 & - & - \\
\hline Chi square-value & - & 0.35 & 0.48 \\
\hline df & 29 & 29 & 29 \\
\hline p-value & 0.164 & 0.550 & 0.490 \\
\hline
\end{tabular}


another lepidopteran pest, Spodoptera eridania Cramer. After repeated applications of calda Viçosa on a cabbage crop (Brassica oleracea var. capitata L.), the authors concluded that the product had neither a direct nor indirect (via plant nutrition) insecticidal effect.

Nonetheless, other studies have shown significant effects of Viça Café Plus against mites and diseases on coffee (Tuelher, 2006). According to Cunha et al. (2004), Viça Café Plus applied preventively on coffee plants was efficient for rust control, especially when applied at low disease incidence, resulting in coffee leaf preservation and suitable yield.

Similarly to Viça Café Plus, concentrations of "supermagro" biofertilizer applied to leaves with L. coffeella eggs were not significantly proportional to egg mortality (Figure 2). The product had neither effect on mine area, not on the number of formed pupae per leaf, and nor on the number of emerged adults per leaf (Table 1). There is only one scientific report testing the efficacy of "supermagro" in controlling the lepidopteran pest Tuta absoluta (Meyrick) on tomatoes (Lycopersicon esculentum Mill.), and its authors found no evidence of insecticidal effect on the pest (Picanço et al., 1999). Research carried out to test the effect of biofertilizers on other arthropod pests also showed the lack of negative effects on thrips (Gonçalves et al., 2004), aphids, beetles (Resende et al., 1987) and mites (Venzon et al., 2006).

Despite the lack of insecticidal effect of Viça Café Plus and "supermagro" against coffee leaf miner, lime sulphur was very toxic to $L$. coffeella eggs (Figure 3). According to the model, the $\mathrm{LC}_{50}(50 \%$ lethal concentration) is $0.37 \%$, and the $\mathrm{LC}_{95}(95 \%$ lethal concentration) is $1.63 \%$. As to larvae development inside mines, however, lime sulphur did not interfere with L. coffeella when applied on mines at early developmental

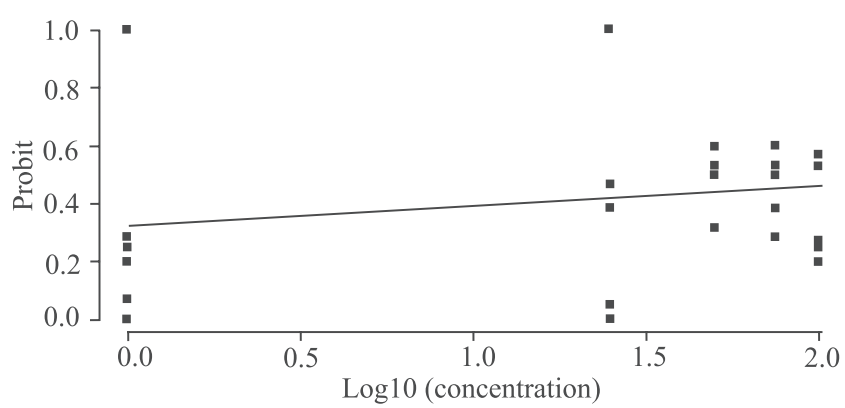

Figure 2. Probit regression line of "supermagro" concentrations on Leucoptera coffeella eggs treated on coffee leaves (Chi $\left.=0.26, \mathrm{df}=34, \mathrm{p}=0.610, \mathrm{R}^{2}=0.03\right)$. stages (Table 1). The size of mines treated with all concentrations of lime sulphur did not differ from the control treatment. No significant difference among the tested concentrations was found for the number of formed pupae per leaf and, therefore, for the number of emerged adults.

In the field, the concentration of lime sulphur and its frequency of spraying interfered with $L$. coffeella infestation 30 days after the start of the experiment, with no interaction between product concentration and spray frequency (Table 2). The number of mined leaves was lower when the product was applied every 15 days

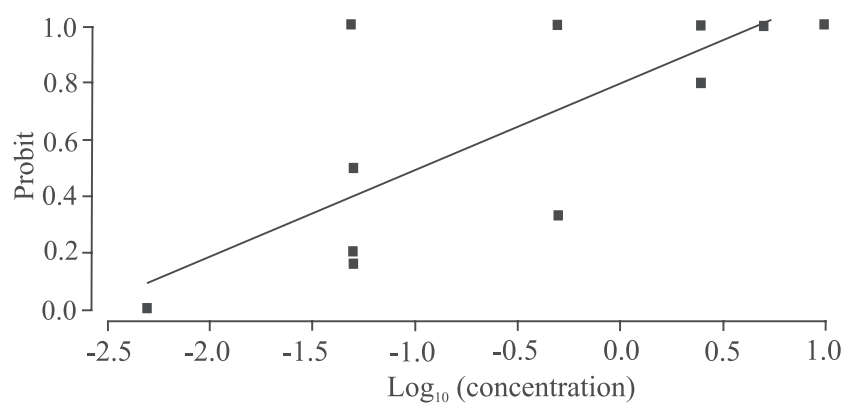

Figure 3. Probit regression line of lime sulphur concentra-tions on Leucoptera coffeella eggs treated on coffee leaves $\left(\mathrm{Chi}=8.3, \mathrm{df}=27, \mathrm{p}=0.004, \mathrm{R}^{2}=0.94\right)$. Probit $=0.800( \pm 0.044)+0.305( \pm 0.037) \log _{10} . \mathrm{LC}_{50}(50 \%$ lethal concentration) $=0.37 \%$ [confidence interval $(\mathrm{CI})$, $0.277-0.473 \%$ ]. LC $\mathrm{C}_{95}$ (95\% lethal concentration) $=1.63 \%$ (CI, 1.483-1.761\%).

Table 2. Statistical analysis summary of the effect of lime sulphur concentrations on the number of Leucoptera coffeella leaf mines.

\begin{tabular}{|c|c|c|c|c|c|}
\hline Factor & df & $\begin{array}{c}\text { Deviance } \\
\text { residual }\end{array}$ & $\begin{array}{c}\mathrm{df} \\
\text { residuals }\end{array}$ & $\begin{array}{c}\text { Chi } \\
\text { value }\end{array}$ & $\begin{array}{c}\mathrm{p} \\
(>\mid \text { Chi } \mid)\end{array}$ \\
\hline & & & 30 days & & \\
\hline Null & - & - & 59 & 185.035 & - \\
\hline Concentration & 1 & 9.104 & 58 & 175.930 & 0.003 \\
\hline Spraying interval ${ }^{(1)}$ & 1 & 15.349 & 57 & 160.582 & $<0.001$ \\
\hline \multirow[t]{2}{*}{ Interaction } & 1 & 4.854 & 56 & 155.728 & 0.028 \\
\hline & & & 60 days & & \\
\hline Null & - & - & 59 & 352.47 & - \\
\hline Concentration & 1 & 14.910 & 58 & 337.97 & 0.150 \\
\hline Spraying interval & 1 & 0.646 & 57 & 337.33 & 0.762 \\
\hline \multirow[t]{2}{*}{ Interaction } & 1 & 1.273 & 56 & 336.06 & 0.670 \\
\hline & & & 90 days & & \\
\hline Null & - & - & 59 & 102.91 & - \\
\hline Concentration & 1 & 0.537 & 58 & 102.37 & 0.544 \\
\hline Spraying interval & 1 & 3.545 & 57 & 98.83 & 0.119 \\
\hline Interaction & 1 & 0.044 & 56 & 98.79 & 0.863 \\
\hline
\end{tabular}

(1) Spraying frequencies were monthly and biweekly. Evaluation was done 30,60 , and 90 days after the beginning of experiments. 
than when applied every 30 days, and it decreased with increasing lime sulphur concentrations (Figure 4). However, the effect of treatments (concentrations and spraying frequency) on the infestation of $L$. coffeella was not significant after 60 days or 90 days from the start of the experiment. In fact, the coffee leaf miner population increased after 60 days for all product tested concentrations, with $14.46 \pm 12.55$ average mines per sample, when lime sulphur was applied biweekly, and 15.27 \pm 7.91 average mines per sample when it was applied monthly. Coffee leaf miner population decreased independently of the product concentration and frequency of spraying, at 90 days from the beginning of the experiment, and attained an average population of $1.23 \pm 1.10$ and $1.84 \pm 1.83$ mines per sample for the biweekly and the monthly treatments, respectively.

Since the reduction in $L$. coffeella population at initial infestation was higher when the product was applied biweekly than when it was applied monthly, the residual effect of lime sulphur may have influenced these results, but there is no information available about it for coffee plants. In citrus, Pattaro (2003) and Andrade et al. (2011) mentioned that lime sulphur had low residual effect for mite control.

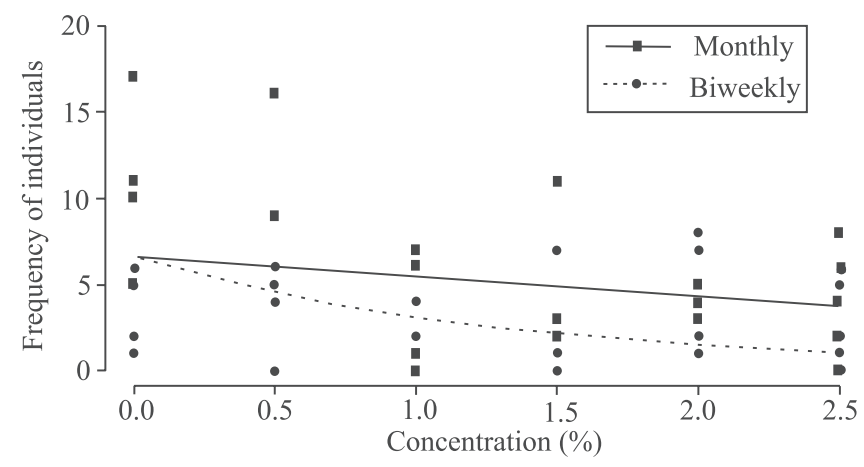

Figure 4. Influence of increasing lime sulphur concentrations on the number of Leucoptera coffeella leaf mines per sampling, on coffee leaves with two spraying intervals during coffee development. Spraying frequency were monthly $(\mathrm{m})$ and biweekly (b). Evaluation was done 30 days after the experiment beginning. The models of spraying on number of mined leaves (y) every 15 days $\left(\mathrm{yb}=\mathrm{e}^{1.8944-0.7337 \mathrm{x}}\right)$ and every 30 days $\left(\mathrm{ym}=\mathrm{e}^{1.8944-0.2271 \mathrm{x}}\right)$, when $\mathrm{x}$ is the concentration.
The increase of coffee leaf miner population observed in the experiment after 30 days of spraying diluted the effects of product concentration and spraying frequency, which became non-significant. It is possible that the population was influenced by lime sulphur concentration only during the initial build-up of the coffee leaf miner population. At the experiment beginning, which coincides with the start of favorable climate conditions for coffee leaf miner (dry season), the population was low (3.06 \pm 2.42 and $5.10 \pm 4.41$ average mines per sample, for biweekly and monthly treatments after 30 days, respectively) and, possibly, it was composed of many eggs, which is the susceptible stage to lime sulphur. However, age distribution of coffee leaf miner population in the field was not recorded. Thus, killing eggs resulted in lower number of mines, but only when coffee leaf miner population was becoming established. Afterwards, as climate conditions became more favorable, egg mortality caused by the products was not sufficient to suppress population growth, since other stages, such as mines, were present, which were not affected by the tested product. Moreover, the decrease in the population after 90 days in all treatments may be due to seasonal distribution of the pest and other uncontrolled factors. Lime sulphur controlled the coffee leaf miner population at the beginning of its establishment. Thus, in the case of using lime sulphur for coffee leaf miner control, it is important to monitor population and use other control measures if population increases.

It is necessary to emphasize the importance of considering field experiments and evaluating different time intervals when testing the efficacy of products for pest control, in order to account for the building up of a pest population. Thus, care should be taken before extrapolating from laboratory results. Lime sulphur was an efficient organic farming-compatible product for reducing coffee leaf miner population at the beginning of the pest season. It is also important to note that no symptoms of phytotoxicity were recorded on coffee plants treated with any lime sulphur tested concentration. Injury due to lime sulphur spraying has been reported for other plants such as apple and citrus (Smilanick \& Sorenson, 2001; Holb et al., 2003). Moreover, the enriched Bordeaux mixture (Viça Café Plus) and the "supermagro" biofertilizer showed no insecticidal effect against $L$. coffeella, despite their current use by organic coffee farmers. 


\section{Conclusions}

1. Enriched Bordeaux mixture (Viça Café Plus) and "supermagro" biofertilizer have no insecticidal effect against coffee leaf miner.

2. Lime sulphur spraying decreases coffee leaf miner population only at the beginning of pest occurrence, even when the product is biweekly or monthly sprayed.

\section{Acknowledgements}

To Conselho Nacional de Desenvolvimento Científico e Tecnológico $(\mathrm{CNPq})$ and to Fundação de Amparo à Pesquisa do Estado de Minas Gerais (Fapemig), for financial support and fellowships.

\section{References}

ABBOTT, W.S. A method of computing the effectiveness of an insecticide. Journal of Economic Entomology, v.18, p.265-267, 1925.

AFONSO, A.P.S.; FARIA, J.L.C.; BOTTON, M.; ZANARDI, O.Z. Avaliação da calda sulfocálcica e do óleo mineral no controle da cochonilha-parda Parthenolecanium persicae (Hemiptera: Coccidae) na cultura da videira. Arquivos do Instituto Biológico, v.74, p.167-169, 2007.

ANDRADE, D.J. de; PATTARO, F.C.; OLIVEIRA, C.A.L. de. Resíduos de calda sulfocálcica sobre a eficiência de acaricidas no controle de Brevipalpus phoenicis. Ciência Rural, v.41, p.1695-1701, 2011. DOI: 10.1590/S0103-84782011005000129.

ANDROCIOLI, H.G.; MENEZES JUNIOR, A. De O.; HOSHINO, A.T.; ANDROCIOLI, L.G. Produtos alternativos no controle da Hemileia vastatrix (Berkeley \& Broome) e Cercospora coffeicola (Berkeley \& Cooke) em cafeeiros. Coffee Science, v.7, p.187-197, 2012.

BEERS, E.H.; MARTINEZ-ROCHA, L.; TALLEY, R.R.; DUNLEY, J.E. Lethal, sublethal, and behavioral effects of sulfur-containing products in bioassays of three species of orchard mites. Journal of Economic Entomology, v.102, p.324-335, 2009. DOI: $10.1603 / 029.102 .0143$.

CRAWLEY, M.J. The R book. Chichester: J. Wiley, 2007. 942p. DOI: $10.1002 / 9780470515075$.

CUNHA, R.L. da; MENDES, A.N.G.; CHALFOUN, S.M. Controle químico da ferrugem do cafeeiro (Coffea arabica L.) e seus efeitos na produção e preservação do enfolhamento. Ciência e Agrotecnologia, v.28, p.990-996, 2004. DOI: 10.1590/ S1413-70542004000500004.

GONÇALVES, P.A.S.; WERNER, H.; DEBARBA, J.F. Avaliação de biofertilizantes, extratos vegetais e diferentes substâncias alternativas no manejo de tripes em cebola em sistema orgânico. Horticultura Brasileira v.22, p.659-662, 2004. DOI: 10.1590/ S0102-05362004000300033.
HERRERA, R.A.U. Controle da ferrugem, da cercosporiose e do bicho-mineiro e nutrição do cafeeiro com a aplicação de calda Viçosa. 1994. 77p. Dissertação (Mestrado) - Universidade Federal de Viçosa, Viçosa.

HOLB, I.J.; DE JONG, P.F.; HEIJNE, B. Efficacy and phytotoxicity of lime sulphur in organic apple production. Annals of Applied Biology, v.142, p.225-233, 2003. DOI: 10.1111/j.1744-7348.2003. tb00245.x.

KIM, D.-S.; SEO, Y.D.; CHOI, K.S. The effects of petroleum oil and lime sulfur on the mortality of Unaspis yanonensis and Aculops pelekassi in the laboratory. Journal of Asia-Pacific Entomology, v.13, p.283-288, 2010. DOI: 10.1016/j.aspen.2010.06.007.

MARTINEZ, S.S.; MENEGUIM, A.M. Redução da oviposição e da sobrevivência de ovos de Leucoptera coffeella causadas pelo óleo emulsionável de nim. Manejo integrado de plagas y Agroecología, v.67, p.58-62, 2003.

MEDEIROS, M.B. de; WANDERLEY, P.A.; WANDERLEY, M.J.A. Biofertilizantes líquidos: processo trofobiótico para proteção de plantas em cultivos orgânicos. Biotecnologia: Ciência e Desenvolvimento, v.31, p.38-44, 2003.

MICHEREFF, M.F.F;; VILELA, E.F.; MICHEREFF-FILHO, M.; THIÈBAUT, J.T. Effects of delayed mating and male mating history on the reproductive potential of Leucoptera coffeella (Lepidoptera: Lyonetiidae). Agricultural and Forest Entomology, v.6, p.241-247, 2004. DOI: 10.1111/j.1461-9555.2004.00227.x.

MICHEREFF-FILHO, M.; TORRES, J.B.; ANDRADE, L.N.T.; NUNES, M.U.C. Effect of some biorational insecticides on Spodoptera eridania in organic cabbage. Pest Management Science, v.64, p.761-767, 2008. DOI: 10.1002/ps.1554.

PALMER, J.W.; DAVIES, S.B.; SHAW, P.W.; WÜNSCHE, J.N. Growth and fruit quality of 'Braeburn' apple (Malus domestica) trees as influenced by fungicide programmes suitable for organic production. New Zealand Journal of Crop and Horticultural Science, v.31, p.169-177, 2003. DOI: 10.1080/01140671.2003.9514249.

PATTARO, F.C. Calda sulfocálcica no agrossistema citrícola. 2003. 73p. Dissertação (Mestrado) - Universidade Estadual Paulista, São Paulo.

PEREIRA, E.J.G.; PICANÇO, M.C.; BACCI, L.; CRESPO, A.L.B.; GUEDES, R.N.C. Seasonal mortality factors of the coffee leafminer, Leucoptera coffeella. Bulletin of Entomological Research, v.97, p.421-432, 2007. DOI: 10.1017/S0007485307005202.

PICANÇO, M.; PALLINI FILHO, A.; LEITE, G.L.D.; MATIOLI, A.L. Avaliação de produtos não convencionais para o controle de Tuta absoluta em tomate. Manejo Integrado de Plagas, v.54, p.27-30, 1999.

R DEVELOPMENT CORE TEAM. R: a language and environment for statistical computing. Vienna: R Foundation for Statistical Computing, 2011.

REIS JUNIOR, R.; LIMA, E.R.; VILELA, E.F.; BARROS, R.S. Method for maintenance of coffee leaves in vitro for mass rearing of Leucoptera coffeellum (Guérin-Méneville) (Lepidoptera: Lyonetiidae). Anais da Sociedade Entomológica do Brasil, v.29, p.849-854, 2000. DOI: 10.1590/S0301-80592000000400030. 
REIS, P.R.; SOUZA, J.C. de; VENZON, M. Manejo ecológico das principais pragas do cafeeiro. Informe Agropecuário, v.23, p.83-99, 2002.

RESENDE, A.M.; FRANÇA, F.H.; CASTELO BRANCO, M.; ROSSI, P.E.F.; SOUZA, A.F. Efeito da consorciação de culturas, adubação química e orgânica, e do uso de biofertilizante e inseticida, sobre as pragas da batata. Horticultura Brasileira, v.5, p.12-15, 1987.

SILVA, B.M.; CARVALHO, A.F. Novo supermagro: o biofertilizante. Viçosa: Centro de Tecnologias Alternativas da Zona da Mata, 2000. 16p.

SMILANICK, J.L.; SORENSON, D. Control of postharvest decay of citrus fruit with calcium polysulfide. Postharvest Biology and Technology, v.21, p.157-168, 2001. DOI: 10.1016/ S0925-5214(00)00142-3.

TUELHER, E.S. Toxicidade de bioprotetores da cafeicultura orgânica sobre o ácaro-vermelho do cafeeiro Oligonychus ilicis e o ácaro predador Iphiseiodes zuluagai. 2006. 59p. Dissertação (Mestrado) - Universidade Federal de Viçosa, Viçosa.
VENZON, M.; OLIVEIRA, R.M.; PEREZ, A.L.; RODRÍGUEZ-CRUZ, F.A.; MARTINS FILHO, S. Lime sulfur toxicity to broad mite, to its host plants and to natural enemies. Pest Management Science, v.69, p.738-743, 2013. DOI: 10.1002/ ps.3431.

VENZON, M.; ROSADO, M. da C.; FADINI, M.A.M.; CIOCIOLA JUNIOR, A.I.; PALLINI, A. The potential of Neem Azal for the control of coffee leaf pests. Crop Protection, v.24, p.213-219, 2005. DOI: 10.1016/j.cropro.2004.07.008.

VENZON, M.; ROSADO, M. da C.; PINTO, C.M.F.; DUARTE, V. da S.; EUZÉBIO, D.E.; PALLINI, A. Potencial de defensivos alternativos para o controle do ácaro branco em pimenta "Malagueta". Horticultura Brasileira, v.24, p.224-227, 2006. DOI: $10.1590 / \mathrm{S} 0102-05362006000200021$.

ZEHNDER, G.; GURR, G.M.; KÜEHNE, S.; WADE, M.R.; WRATTEN, S.D; WYSS, E. Arthropod pest management in organic crops. Annual Review of Entomology, v.52, p.57-80, 2007. DOI: 10.1146/annurev.ento.52.110405.091337.

Received on December 17, 2012 and accepted on March 1 ${ }^{\text {st }}, 2013$ 